\title{
Formulação de rações para leitões com base nos nutrientes digestíveis da silagem de grãos úmidos de milho
}

\author{
Vanessa Sousa Castro ${ }^{1}$, Dirlei Antonio Berto ${ }^{2}$, Messias Alves da Trindade Neto $^{3}$, Marco \\ Antônio Martin Biaggioni ${ }^{4}$, Francisco Stefano Wechsler ${ }^{3}$, Anália Maria Ribeiro da Silva ${ }^{2}$
}

1 Programa de pós-graduação em Zootecnia, Faculdade de Medicina Veterinária e Zootecnia - Universidade Estadual Paulista (UNESP) Botucatu, SP, Brasil.

2 Departamento de Produção Animal, Faculdade de Medicina Veterinária e Zootecnia - Universidade Estadual Paulista (UNESP) - Botucatu, SP, Brasil.

${ }^{3}$ Departamento de Nutrição e Produção Animal, Faculdade de Zootecnia e Engenharia de Alimentos - Universidade de São Paulo (USP) Pirassununga, SP, Brasil.

${ }^{4}$ Departamento de Engenharia Rural, Faculdade de Ciências Agronômicas - Universidade Estadual Paulista (UNESP) - Botucatu, SP, Brasil.

RESUMO - O estudo foi realizado com o objetivo de avaliar o resultado econômico e o desempenho de leitões na fase de creche alimentados com rações formuladas com base nos nutrientes digestíveis da silagem de grãos úmidos de milho. Foram utilizados 18 leitões mestiços (Landrace $\times$ Large White) com peso médio inicial de 16,01 kg no experimento de digestibilidade e 60 leitões mestiços com peso médio inicial de $7,11 \mathrm{~kg}$ no experimento de desempenho. O delineamento experimental nos dois experimentos foi em blocos ao acaso. No experimento de digestibilidade, avaliou-se uma ração-referência contendo ou não $30 \%$ de milho seco moído (30\%) e silagem de grãos úmidos de milho e, no experimento de desempenho, avaliaram-se quatro rações: à base de grãos de milho seco moídos; à base de silagem de grãos úmidos de milho (SGUM) em substituição a 100\% do milho seco, com base na matéria seca; à base de SGUM, considerando o valor de energia digestível da silagem determinado no experimento de digestibilidade; e à base de SGUM, considerando os valores de energia digestível, proteína digestível e fósforo disponível da silagem, determinados no experimento de digestibilidade. A digestibilidade aparente de matéria seca (MS), proteína bruta (PB), fósforo $(\mathrm{P})$ e cálcio $(\mathrm{Ca})$ e o nível de energia digestível foram maiores para a ração à base de SGUM formulada considerando os valores nutricionais determinados no experimento de digestibilidade. Durante o período total do experimento de desempenho (0 a 32 dias), a SGUM proporcionou melhor conversão alimentar e os menores custos/kg de peso ganho, mas não foram observadas diferenças no ganho diário de peso e no consumo diário de ração. Na formulação de rações com silagem de grãos úmidos de milho para suínos, deve-se considerar o valor nutricional, principalmente o teor de energia digestível, desse alimento.

Palavras-chave: conservação de grãos, desempenho, digestibilidade, fósforo, suínos

\section{Feed formulation for piglets based on digestible nutrients of high moisture corn silage}

\begin{abstract}
A study was conducted to evaluate the economic results and the performance of nursery piglets fed diets based on the digestible nutrients of high-moisture corn silage (HMCS). Eighteen crossbred piglets (Landrace $\times$ Large White) with an average initial weight of $16.01 \mathrm{~kg}$, were used in the digestibility experiment and 60 crossbred piglets, with an average initial weight of $7.11 \mathrm{~kg}$ were used in the performance experiment. A randomized block design was used in both experiments. In the digestibility experiment, a reference feed was assessed containing, or not, 30\% ground dried corn and high moisture corn silage and the performance experiment assessed four feeds: based on ground dried corn grains, based on SGUM, considering the digestible energy value of the silage determined in the digestibility experiment and based on SGUM considered the digestible energy, digestible protein and available phosphorus values of the silage, determined in the digestibility experiment. The dry matter apparent digestibility, crude protein, phosphorus and calcium and the digestible energy level were greater for the feed based on formulated SGUM considering the nutritional values determined in the digestibility experiment. Throughout the performance experiment (0 to 32 days) SGUM gave better feed conversion and lower cost $/ \mathrm{kg}$ weight gain, but differences were not observed in the daily weight gain and daily feed intake. In formulating feeds with high moisture corn grains for pigs, the nutritional value should be considered, especially the digestible energy content of this feeds.
\end{abstract}

Key Words: digestibility, grain conservation, performance, phosphorus, swine 


\section{Introdução}

A intensificação da produção suinícola e a adoção do desmame antecipado visando ao aumento do potencial produtivo da matriz, expresso pela quantidade de leitões desmamados por porca por ano, impôs grandes desafios aos nutricionistas, pois é necessária adequada combinação dos ingredientes, além de conhecimento da biodisponibilidade dos nutrientes das matérias primas, para reduzir os problemas da fase pós-desmame (Trindade Neto et al., 1994).

No sistema de produção de suínos, a fase de creche é a mais problemática, em decorrência dos fatores estressantes que se impõem aos leitões, como: separação da mãe, mudança de ambiente, reagrupamento social e mudança brusca na alimentação. A substituição da dieta líquida à base de leite materno pela dieta sólida à base de cereais predispõe os leitões a problemas gastrintestinais, uma vez que o sistema digestório ainda está imaturo e não possui secreção suficiente de ácido clorídrico, desse modo, a inclusão de acidificantes nas rações tem sido uma prática comum, mas que onera seus custos.

A silagem de grãos úmidos de milho é considerada uma alternativa na formulação de rações para suínos, com a vantagem da acidificação natural durante o processo de ensilagem. Muitos autores demonstraram a superioridade da silagem com relação à conversão alimentar, ao ganho de peso e à diminuição na incidência da diarreia pósdesmame em comparação ao milho seco (Lopes et al., 2001a,b; Tófoli et al., 2006; Tse et al., 2006).

A crescente preocupação com a poluição ambiental aumentou o interesse por alternativas que melhorem o desempenho animal e também reduzam o impacto ambiental causado pelos dejetos. Desse modo, busca-se atender com maior precisão as exigências nutricionais dos suínos, considerando os teores de nutrientes digestíveis das matérias-primas das rações.

Segundo Tófoli et al. (2006) e Tse et al. (2006), a silagem de grãos úmidos de milho apresenta maiores valores de energia digestível e de energia metabolizável, em comparação ao milho seco para leitões. Maiores coeficientes de digestibilidade aparente do fósforo e do cálcio foram verificados por Tse et al. (2006) para a silagem de grãos úmidos de milho, o que atribuiu-se à provável ação do processo de ensilagem sobre o fósforo fítico.

O objetivo nesta pesquisa foi avaliar o valor nutricional da silagem de grãos úmidos de milho (SGUM) e as formas de substituição do milho seco pela silagem nas rações sobre o resultado econômico e o desempenho de leitões na fase de creche.

\section{Material e Métodos}

Foram realizados dois experimentos com o mesmo híbrido de milho, produzido nas mesmas condições de solo, clima e tratos culturais para a produção da silagem e do milho seco. Os grãos úmidos, após a colheita com $65,19 \%$ de matéria seca, foram triturados e ensilados em tambores plásticos de 200 litros, com tampa de rosca, conforme Costa et al. (1999), enquanto o milho seco foi colhido 30 dias depois, submetido a processo de secagem $(87,07 \%$ de matéria seca) e armazenado ensacado.

No experimento de digestibilidade, foram utilizados 18 leitões mestiços (Landrace $\times$ Large White), machos castrados, com peso inicial médio de 16,01 kg, alojados em gaiolas para estudo de metabolismo, semelhante às descritas por Pekas (1968). O período experimental teve duração de 10 dias: cinco de adaptação dos animais às gaiolas e às dietas experimentais e cinco de coleta.

O delineamento experimental utilizado foi o de blocos ao acaso, com três tratamentos e seis repetições. O critério utilizado para formação dos blocos foi o peso dos animais. Avaliaram-se: ração referência (Tabela 1); mistura composta de $70 \%$ de ração referência e $30 \%$ de milho seco moído e mistura composta de $70 \%$ de ração referência e $30 \%$ de silagem de grãos úmidos de milho. As rações foram formuladas para atender no mínimo as exigências nutricionais propostas pelo NRC (1998).

O milho seco e a silagem substituíram a ração-referência com base na matéria seca. Os animais foram alimentados

Tabela 1 - Composição da ração-referência

\begin{tabular}{|c|c|}
\hline Ingrediente & $\%$ \\
\hline Milho moído & 62,800 \\
\hline Farelo de soja & 27,500 \\
\hline Açúcar & 3,000 \\
\hline Óleo de soja & 2,606 \\
\hline Fosfato bicálcico & 2,350 \\
\hline Calcário & 0,410 \\
\hline Sal & 0,350 \\
\hline L-lisina HCL & 0,530 \\
\hline DL-metionina & 0,100 \\
\hline L-triptofano & 0,030 \\
\hline L-treonina & 0,024 \\
\hline Mistura mineral e vitamínica ${ }^{1}$ & 0,300 \\
\hline \multicolumn{2}{|l|}{ Valores nutricionais (analisados) } \\
\hline Matéria seca $(\%)$ & 88,30 \\
\hline Proteína bruta $(\%)^{2}$ & 20,185 \\
\hline Cálcio, $\%^{2}$ & 0,890 \\
\hline Fósforo total, $\%^{2}$ & 0,785 \\
\hline \multicolumn{2}{|c|}{$\begin{array}{l}{ }^{1} \text { Suprindo as seguintes quantidades por kg de ração: } 75 \mathrm{mg} \text { de Fe; } 7,5 \mathrm{mg} \mathrm{de} \mathrm{Cu} \text {; } \\
50 \mathrm{mg} \text { de Mn; } 75 \mathrm{mg} \text { de } \mathrm{Zn} ; 1,5 \mathrm{mg} \text { de Co; } 0,5 \mathrm{mg} \text { de I; } 0,25 \mathrm{mg} \text { de Se; } 10000 \mathrm{Ul} \\
\text { vit. A; } 1500 \text { UI vit D3; } 30 \mathrm{mg} \text { vit. E; } 2,0 \mathrm{mg} \text { vit. K3; } 2,0 \mathrm{mg} \text { vit. B1; } 5,0 \mathrm{mg} \text { vit. } \\
\text { B2; } 3,0 \mathrm{mg} \text { vit. B6; } 30 \mathrm{mcg} \text { vit. B12; } 0,80 \mathrm{mg} \text { ácido fólico; } 12 \mathrm{mg} \text { ácido } \\
\text { pantotênico; } 30 \mathrm{mg} \text { niacina. } \\
2 \text { Valores expressos na matéria natural. }\end{array}$} \\
\hline
\end{tabular}


duas vezes ao dia, às $8 \mathrm{~h}$ e às $17 \mathrm{~h}$. A quantidade diária fornecida foi estabelecida de acordo com o consumo na fase de adaptação, baseando-se no animal de menor consumo dentro de cada bloco e no peso metabólico (PV $\left.{ }^{0,75}\right)$ dos animais.

As rações foram umedecidas com água antes de cada refeição com os objetivos de diminuir a pulverulência e o desperdício e facilitar o consumo. Após cada refeição, forneceu-se água à vontade aos animais.

Utilizou-se o método da coleta total de fezes. Para definir o início e o final do período de coleta, adicionou-se 1,5\% de óxido férrico $\left(\mathrm{Fe}_{2} \mathrm{O}_{3}\right)$ às rações. As fezes totais produzidas foram coletadas diariamente às $8 \mathrm{~h}$, armazenadas em sacos plásticos, pesadas, identificadas e colocadas em freezer.

Ao término do período de coleta, as amostras de fezes foram homogeneizadas e uma amostra representativa de cada animal foi retirada para secagem em estufa com ventilação forçada a $55^{\circ} \mathrm{C}$ por um período de 60 horas e, em seguida, moída.

Foi empregado o método de Matterson et al. (1965) para cálculo dos valores dos coeficientes de digestibilidade aparente de matéria seca, proteína bruta, cálcio e fósforo e dos teores de energia digestível dos alimentos-teste.

O milho seco e a silagem foram submetidos à análise de $\mathrm{pH}$ e de diâmetro geométrico médio das partículas, segundo metodologia descrita por Zanotto \& Bellaver(1996).

Os dados de digestibilidade foram submetidos à análise de variância pelo programa estatístico SAS (1998).

No experimento de desempenho, utilizaram-se 60 leitões mestiços (Landrace $\times$ Large White), com idade média de 28 dias e peso médio inicial de $7,11 \mathrm{~kg}$. Os animais foram alojados em salas de creche de alvenaria, contendo 20 baias metálicas suspensas, medindo $1,0 \times 1,75 \mathrm{~m}$, equipadas com comedouro, bebedouro tipo chupeta e campânula para aquecimento, durante todo o período experimental (28 a 60 dias de idade). O delineamento experimental utilizado foi o de blocos ao acaso com quatro tratamentos e cinco repetições. Os critérios para a formação dos blocos foram o peso, o sexo e o parentesco dos animais.

A unidade experimental foi formada por três leitões. A cada parcela, aleatoriamente, atribuíram-se: rações à base de grãos de milho seco moído; rações à base de silagem de grãos úmidos de milho (SGUM) em substituição a 100\% do milho seco, com base na matéria seca; rações à base de SGUM, considerando o valor de energia digestível da silagem determinado no experimento de digestibilidade; rações à base de SGUM, considerando os valores de energia digestível, proteína digestível e fósforo disponível da silagem determinados no experimento de digestibilidade.
A disponibilidade relativa de fósforo foi estimada para a silagem a partir da relação entre digestibilidade e disponibilidade. Foram considerados os coeficientes de digestibilidade do fósforo determinados no primeiro experimento $(45,32 \%$ para o milho seco e $64,80 \%$ para a silagem) e o valor de $14 \%$ de biodisponibilidade do fósforo no milho seco, de acordo com o NRC (1998), obtendo-se, desse modo, o valor relativo de disponibilidade do fósforo na silagem $(20,01 \%)$.

Os teores dos nutrientes da SGUM foram corrigidos para o mesmo teor de matéria seca determinada para o milho $\operatorname{seco}(87,07 \%)$. Esse valor foi utilizado na matriz de formulação para cálculo das rações à base de SGUM, considerando o valor de energia digestível da silagem determinado no ensaio 1; e das rações à base de SGUM, considerando os valores de energia digestível, proteína digestível e fósforo disponível da silagem determinados no ensaio 1 .

Diariamente, a partir dos respectivos concentrados, as rações foram preparadas em misturador com capacidade para $50 \mathrm{~kg}$. A quantidade de silagem de grãos úmidos de milho nos tratamentos foi ajustada com base no fator de correção, considerando os teores originais de matéria seca do milho e da silagem.

Durante o período experimental (32 dias), foram fornecidas três rações à vontade: ração pré-inicial nos primeiros 10 dias; ração inicial 1 do $10^{\circ}$ ao $24^{\circ}$ dia e ração inicial 2 , do $24^{\circ}$ ao $32^{\circ}$ dia. As rações foram formuladas para atender no mínimo às exigências nutricionais propostas pelo NRC (1998), exceto para proteína bruta, para cada uma das fases estudadas (Tabelas 2 e 3 ).

O estudo da viabilidade econômica da substituição do milho seco pela silagem de grãos úmidos de milho nas rações foi realizado com base no custo de ração por quilograma de peso ganho (CR/kg GP), determinado segundo Bellaver et al. (1985).

As características de desempenho e o custo de ração/ $\mathrm{kg}$ de peso ganho foram submetidos à análise de variância e as médias comparadas pelo teste de Tukey utilizando-se o programa estatístico SAS (1998).

\section{Resultados e Discussão}

A composição bromatológica do milho seco e da silagem (Tabela 4) foi semelhante às encontradas na literatura para proteína bruta (Jobim et al., 1997; Tófoli et al., 2006 e Tse et al., 2006), cálcio (EMBRAPA, 1991; Oliveira et al., 2004) e fósforo (Oliveira et al., 2004; Tófoli et al., 2006; Tse et al., 2006).

Os valores de $\mathrm{pH}$ determinados na silagem e no milho seco podem ser considerados adequados, pois, de acordo 
com Shaver (2000), uma silagem de boa qualidade deve possuir pH de 3,8 a 4,2. O diâmetro geométrico médio (DGM) do milho seco moído esteve na faixa de 500 a $650 \mu \mathrm{m}$, recomendada por Zanotto et al. (1995) e Zardo \& Lima (1999), enquanto o diâmetro geométrico médio (DGM) da silagem manteve-se no intervalo de 979 a $1168 \mu \mathrm{m}$ preconizado por Tse et al. (2006).

Em todos os parâmetros avaliados, a silagem de grãos úmidos de milho foi superior $(\mathrm{P}<0,05)$ ao milho seco, evidenciando seu maior valor nutricional para leitões, o que pode, em parte, ser atribuído ao seu menor $\mathrm{pH}$, uma vez que Holmes et al. (1974), trabalhando com suínos, concluíram que o aumento da acidez total da dieta, provocada pela presença de milho úmido preservado com ácidos orgânicos, determinou maior retenção estomacal e fluxo mais uniforme da digesta para o intestino delgado no intervalo das refeições.
Além disso, Tossenberger et al. (1993) afirmaram que o baixo $\mathrm{pH}$ da silagem pode ser responsável pela hidrólise do fitato presente nos grãos (Tabela 5).

Outras prováveis razões determinantes do maior valor nutricional da SGUM seriam o elevado teor de umidade e as alterações no endosperma dos grãos durante a ensilagem, como o rompimento parcial da matriz proteica que envolve os grânulos de amido e as alterações estruturais que ocorrem nesses grânulos (Berto et al., 2001; Lopes et al., 2001 a,b; Lopes et al., 2002), possivelmente causadas pela associação dos fatores durante a ensilagem como tempo, temperatura, umidade e acidez (Lopes et al., 2002).

Os valores de energia digestível (ED) e os coeficientes de digestibilidade aparente da matéria seca (MS) e da proteína bruta (PB) do milho seco e da SGUM foram próximos aos valores determinados por Tse et al. (2006),

Tabela 2 - Composição das rações à base de grãos de milho seco moído e das rações à base de silagem de grãos úmidos de milho

\begin{tabular}{|c|c|c|c|c|c|c|}
\hline \multirow[b]{2}{*}{ Ingrediente } & \multicolumn{3}{|c|}{ Rações à base de grãos de milho seco moído } & \multicolumn{3}{|c|}{ Rações à base de silagem de grãos úmidos de milho } \\
\hline & 28 a 38 dias & 38 a 52 dias & 52 a 60 dias & 28 a 38 dias & 38 a 52 dias & 52 a 60 dias \\
\hline Milho moído & 51,711 & 56,654 & 65,089 & 0,000 & 0,000 & 0,000 \\
\hline Silagem de grãos úmidos de milho ${ }^{1}$ & 0,000 & 0,000 & 0,000 & 51,711 & 56,654 & 65,089 \\
\hline Soja farelo & 20,000 & 23,090 & 24,000 & 20,000 & 23,090 & 24,000 \\
\hline Soro de leite & 8,000 & 5,000 & 0,000 & 8,000 & 5,000 & 0,000 \\
\hline Açúcar & 3,000 & 2,000 & 2,000 & 3,000 & 2,000 & 2,000 \\
\hline Células sanguíneas & 1,800 & 2,200 & 1,000 & 1,800 & 2,200 & 1,000 \\
\hline Plasma sanguíneo & 3,000 & 1,200 & 0,000 & 3,000 & 1,200 & 0,000 \\
\hline Maltodextrina & 5,000 & 3,000 & 0,000 & 5,000 & 3,000 & 0,000 \\
\hline Fosfato bicálcico & 1,870 & 1,430 & 1,210 & 1,870 & 1,430 & 1,210 \\
\hline Óleo de soja & 1,900 & 2,200 & 3,300 & 1,900 & 2,200 & 3,300 \\
\hline Calcário calcítico & 0,680 & 0,800 & 0,920 & 0,680 & 0,800 & 0,920 \\
\hline Sal $(\mathrm{NaCl})$ & 0,300 & 0,350 & 0,350 & 0,300 & 0,350 & 0,350 \\
\hline Óxido de zinco & 0,300 & 0,000 & 0,000 & 0,300 & 0,000 & 0,000 \\
\hline L-lisina $\mathrm{HCl}$ & 0,480 & 0,260 & 0,336 & 0,480 & 0,260 & 0,336 \\
\hline DL-metionina & 0,124 & 0,063 & 0,030 & 0,124 & 0,063 & 0,030 \\
\hline L-triptofano & 0,035 & 0,000 & 0,000 & 0,035 & 0,000 & 0,000 \\
\hline L-treonina & 0,200 & 0,083 & 0,095 & 0,200 & 0,083 & 0,095 \\
\hline Cloreto de colina & 0,050 & 0,050 & 0,050 & 0,050 & 0,050 & 0,050 \\
\hline Sulfato de cobre & 0,000 & 0,070 & 0,070 & 0,000 & 0,070 & 0,070 \\
\hline Mistura vitamínica ${ }^{2}$ & 0,100 & 0,100 & 0,100 & 0,100 & 0,100 & 0,100 \\
\hline Mistura mineral ${ }^{3}$ & 0,100 & 0,100 & 0,100 & 0,100 & 0,100 & 0,100 \\
\hline Adsorvente 4 & 0,350 & 0,350 & 0,350 & 0,350 & 0,350 & 0,350 \\
\hline Glúten de milho & 1,000 & 1,000 & 1,000 & 1,000 & 1,000 & 1,000 \\
\hline \multicolumn{7}{|l|}{ Valores nutricionais (calculados) } \\
\hline Energia digestível, $\mathrm{kcal} / \mathrm{kg}^{5}$ & 3.421 & 3.401 & 3.386 & 3.573 & 3.567 & 3.577 \\
\hline Proteína bruta, \% & 20,04 & 20,24 & 19,04 & 19,61 & 19,77 & 18,51 \\
\hline Cálcio, \% & 0,83 & 0,75 & 0,72 & 0,83 & 0,75 & 0,72 \\
\hline Fósforo total, \% & 0,63 & 0,55 & 0,50 & 0,65 & 0,57 & 0,52 \\
\hline Fósforo disponível, $\%{ }^{5}$ & 0,45 & 0,35 & 0,28 & 0,46 & 0,36 & 0,29 \\
\hline Proteína digestível, $\% 5$ & 16,91 & 16,85 & 15,50 & 17,09 & 17,05 & 15,73 \\
\hline Lisina total, $\%$ & 1,47 & 1,29 & 1,18 & 1,47 & 1,29 & 1,18 \\
\hline Metionina total, $\%$ & 0,42 & 0,37 & 0,32 & 0,42 & 0,37 & 0,32 \\
\hline Triptofano total, $\%$ & 0,27 & 0,24 & 0,21 & 0,27 & 0,24 & 0,21 \\
\hline Treonina total, $\%$ & 1,00 & 0,88 & 0,79 & 1,00 & 0,88 & 0,79 \\
\hline
\end{tabular}


Tabela 3 - Composição das rações à base de grãos de milho seco moído e das rações à base de silagem de grãos úmidos de milho

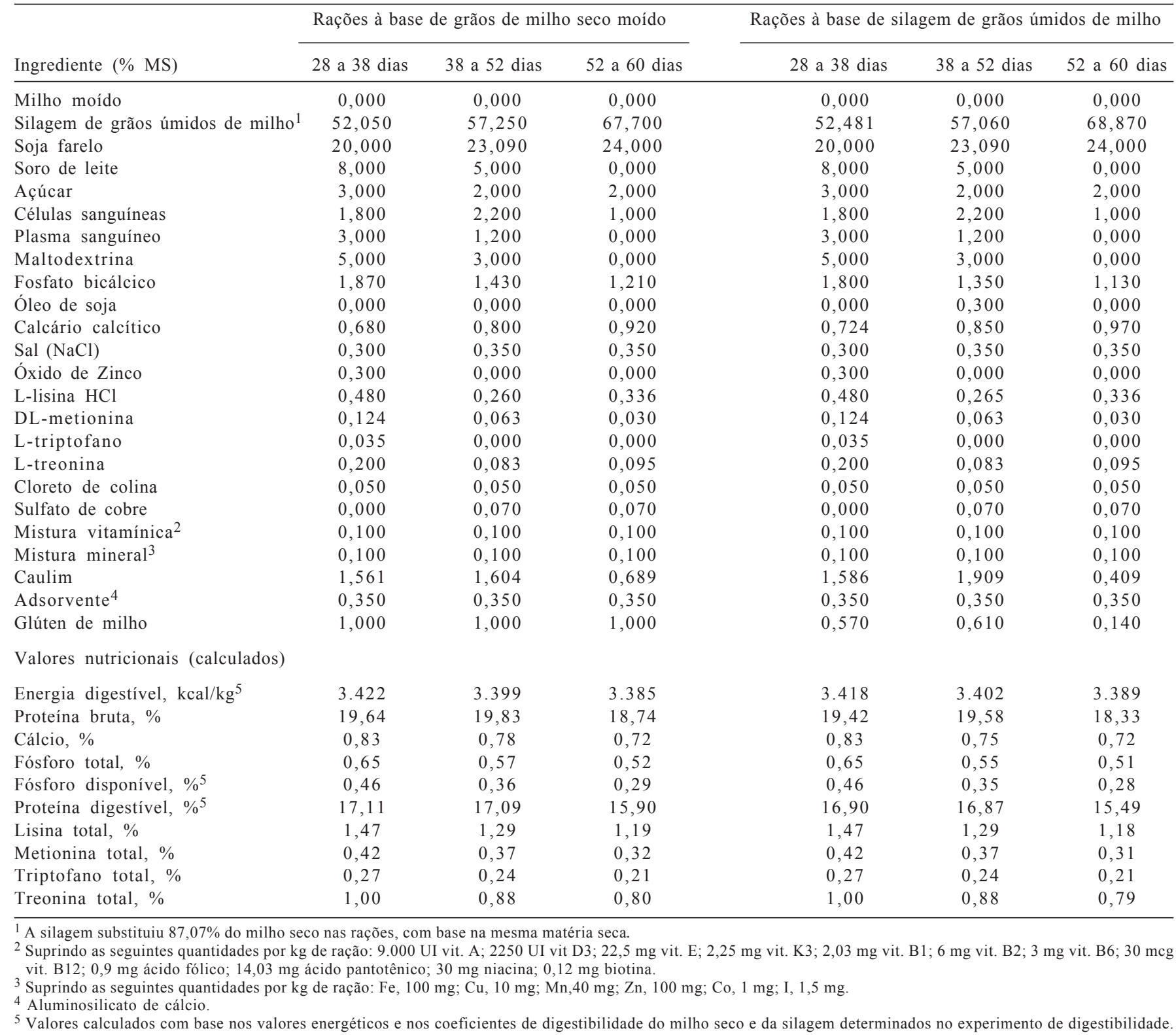

Tabela 4 - Composição nutricional, pH e de diâmetro geométrico médio (DGM) das partículas da silagem e do milho seco moído ${ }^{1}$

\begin{tabular}{lcccccc}
\hline Milho & $\begin{array}{c}\mathrm{MS} \\
\%\end{array}$ & $\begin{array}{c}\mathrm{PB}^{1} \\
\%\end{array}$ & $\begin{array}{c}\mathrm{Ca}^{1} \\
\%\end{array}$ & $\begin{array}{c}\mathrm{P}^{1} \\
\%\end{array}$ & $\mathrm{pH}$ & $\begin{array}{c}\text { DGM } \\
(\mu \mathrm{m})\end{array}$ \\
\hline Seco & 87,07 & 11,20 & 0,020 & 0,250 & 6,07 & 557 \\
Silagem & 65,19 & 10,24 & 0,020 & 0,280 & 3,92 & 1018 \\
\hline
\end{tabular}

1 Valores expressos na matéria seca.

que também encontraram maiores coeficientes de digestibilidade aparente do cálcio e do fósforo para a silagem em relação ao milho seco.

No experimento de desempenho não houve efeito $(\mathrm{P}>0,05)$ das rações no consumo diário de ração $(C D R)$ e no ganho diário de peso (GDP) (Tabela 6). Ausência de efeitos da silagem de grãos úmidos de milho nessas variáveis durante a fase de creche foi destacada por Tófoli et al. (2006) e Tse et al. (2006). Entretanto, Rangrab et al. (2004), verificaram que leitões alimentados com SGUM apresentaram menor CDR em relação aos alimentados com milho seco.

A conversão alimentar dos leitões que receberam SGUM foi melhor $(\mathrm{P}<0,06)$ que a daqueles que receberam milho seco, especialmente no período total do experimento, o que está de acordo com os resultados obtidos por Lopes et al. (2001 a,b); Tófoli et al. (2006) e Tse et al. (2006).

As rações à base de grãos de milho seco moído e as rações à base de silagem de grãos úmidos de milho em 
Tabela 5 - Digestibilidade aparente da matéria seca e de nutrientes do milho seco e da silagem ${ }^{1}$

\begin{tabular}{lccc}
\hline Digestibilidade aparente & Milho seco & Milho silagem & Coeficiente de variação (\%) \\
\hline Matéria seca & $81,17 \mathrm{a}$ & $86,14 \mathrm{~b}$ & 4,19 \\
Proteína bruta & $63,35 \mathrm{a}$ & $73,26 \mathrm{~b}$ & 7,64 \\
Cálcio & $59,07 \mathrm{a}$ & $74,81 \mathrm{~b}$ & 9,58 \\
Fósforo & $45,32 \mathrm{a}$ & $64,80 \mathrm{~b}$ & 16,68 \\
Energia digestível (kcal/kg de MS) & $3,696 \mathrm{a}$ & $4,034 \mathrm{~b}$ & 4,89 \\
\hline
\end{tabular}

${ }^{1}$ Médias seguidas de letras distintas diferem $(\mathrm{P}<0,05)$.

Tabela 6 - Consumo e ganho diário de peso e conversão alimentar de leitões nos primeiros dez dias e durante todo o período experimental ${ }^{1}$

\begin{tabular}{|c|c|c|c|c|c|c|}
\hline \multirow[t]{2}{*}{ Período (dias) } & \multirow[t]{2}{*}{ Característica } & \multicolumn{4}{|c|}{ Ração } & \multirow{2}{*}{$\begin{array}{l}\text { CV } \\
(\%)\end{array}$} \\
\hline & & $1^{3}$ & $2^{3}$ & $3^{3}$ & $4^{3}$ & \\
\hline \multirow{2}{*}{0 a 10} & Consumo diário de ração, $\mathrm{g}^{2}$ & 594 & 526 & 531 & 540 & 9,60 \\
\hline & Conversão alimentar ${ }^{2}$ & $1,44 \mathrm{a}$ & $1,27 \mathrm{~b}$ & $1,27 b$ & $1,30 \mathrm{ab}$ & 6,92 \\
\hline \multirow[b]{2}{*}{0 a 32} & Consumo diário de ração, $\mathrm{g}^{2}$ & 938 & 861 & 867 & 898 & 7,36 \\
\hline & Ganho de peso diário, g & 501 & 562 & 555 & 568 & 12,83 \\
\hline
\end{tabular}

CV = coeficiente de variação.

${ }_{1}^{1}$ Médias seguidas com letras distintas diferem $(\mathrm{P}<0,06)$ pelo teste de Tukey .

${ }^{2}$ Valores corrigidos para a mesma base de matéria seca do milho seco.

${ }^{3} 1$ - Rações à base de grãos de milho seco moído. 2 - Rações à base de silagem de grãos úmidos de milho, substituindo $100 \%$ do milho seco com base na matéria seca. 3 - Rações à base de silagem de grãos úmidos de milho, considerando o valor de ED da silagem determinado no experimento de digestibilidade. 4 - Rações à base de silagem de grãos úmidos de milho, considerando os valores de ED, proteína digestível e fósforo disponível da silagem determinados no experimento de digestibilidade.

substituição a $100 \%$ do milho seco, embora tenham sido balanceadas para apresentar mesmos níveis de energia digestível, proteína digestível e fósforo disponível, determinaram diferença na conversão alimentar média dos animais no período total do experimento. A conversão alimentar dos leitões que receberam silagem foi melhor que a daqueles que receberam milho seco, demonstrando que no primeiro experimento, embora os coeficientes de digestibilidade e a energia digestível determinados para a silagem tenham sido superiores ao do milho seco e semelhantes aos observados por outros pesquisadores, o valor nutricional da silagem foi subestimado. Esse fato pode ser atribuído às limitações e restrições da própria metodologia dos experimentos de digestibilidade com coleta total de fezes e às características próprias da silagem, como o menor pH e a presença de ácidos orgânicos que atuariam como fatores controladores do crescimento da flora microbiana indesejável no trato digestório e também promoveriam aumento na digestibilidade dos demais componentes da ração. Pupa et al. (1999) concluíram que a suplementação de ácido fumárico na ração de leitões desmamados promove aumento nos coeficientes de digestibilidade da energia bruta, matéria seca e da proteína bruta, o que foi atribuído ao sinergismo do ácido sobre a utilização dos nutrientes da ração.

Os resultados da análise econômica indicaram grande vantagem para as rações com SGUM, pois o custo por quilograma de ganho de peso foi, em média, 20\% menor. Embora não tenha havido diferenças estatísticas entre as dietas com silagem, as rações à base de silagem de grãos úmidos de milho, formuladas considerando o valor de energia digestível ou os valores de energia digestível, proteína digestível e fósforo disponível da silagem, resultaram em custo de ração por $\mathrm{kg}$ de peso ganho em torno de $5 \%$ menor em comparação àquelas em que a silagem substituiu o milho seco apenas com base na matéria seca (Tabela 7).

Tabela 7 - Custo médio do quilograma de ração e custo de ração por quilograma de peso ganho $(\mathrm{CR} / \mathrm{kg} \mathrm{GP})$ dos leitões durante o período total do experimento ${ }^{1}$

\begin{tabular}{|c|c|c|c|c|}
\hline \multirow[b]{2}{*}{ Custo da ração - $\mathrm{R} \$ / \mathrm{kg}^{3}$} & \multicolumn{4}{|c|}{ Ração ${ }^{2}$} \\
\hline & 1 & 2 & 3 & 4 \\
\hline - ração pré-inicial & 1,08 & 1,08 & 1,05 & 1,04 \\
\hline - ração inicial 1 & 0,76 & 0,75 & 0,72 & 0,72 \\
\hline - ração inicial 2 & 0,49 & 0,48 & 0,43 & 0,42 \\
\hline $\begin{array}{l}\text { Consumo de ração, } \\
\mathrm{R} \$ / \mathrm{kg} \text { ganho de peso }\end{array}$ & $1,36 \mathrm{a}$ & $1,12 b$ & $1,05 b$ & $1,06 \mathrm{~b}$ \\
\hline \multicolumn{5}{|c|}{$\begin{array}{l}{ }^{1} \text { Médias seguidas com letras distintas na linha diferem }(\mathrm{P}<0,05) \text { pelo teste de } \\
\text { Tukey. } \\
2 \text { 1- Rações à base de grãos de milho seco moído. } 2 \text { - Rações à base de silagem de } \\
\text { grãos úmidos de milho, substituindo } 100 \% \text { do milho seco com base na matéria } \\
\text { seca. } 3 \text { - Rações à base de silagem de grãos úmidos de milho, considerando o } \\
\text { valor de ED da silagem determinado no experimento de digestibilidade. } 4 \\
\text { rações à base de silagem de grãos úmidos de milho, considerando os valores de } \\
\text { ED, proteína digestível e fósforo disponível da silagem determinados no } \\
\text { experimento de digestibilidade. } \\
{ }^{3} \text { Os preços dos ingredientes das rações foram levantados no mês de maio de } 2006 \text {. }\end{array}$} \\
\hline
\end{tabular}




\section{Conclusões}

Os valores dos nutrientes digestíveis determinados pelo método de coleta total de fezes subestimam o valor nutricional da silagem de grãos úmidos de milho. A melhor conversão alimentar dos leitões alimentados com rações contendo silagem é a principal responsável pelo menor custo de ração por kg de peso ganho. O valor nutricional da silagem, especialmente energia digestível, deve ser considerado na formulação de rações para leitões.

\section{Literatura Citada}

BELlAVER, C.; FIALHO, E.T.; PROTAS, J.F.S. et al. Radícula de malte na alimentação de suínos em crescimento e terminação. Pesquisa Agropecuária Brasileira, v.20, n.8, p.969-974, 1985.

BERTO, D.A.; LOPES, A.B.F.C.; COSTA, C. Silagem de grãos úmidos para suínos. In: SIMPÓSIO SOBRE MANEJO E NUTRIÇÃO DE AVES E SUÍNOS E TECNOLOGIA DA PRODUÇÃO DE RAÇÕES, 2001, Campinas. Anais... Campinas: Colégio Brasileiro de Nutrição Animal, 2001. p.203-218.

COSTA, C.; ARRIGONI, M.D.B.; SILVEIRA, A.C. et al. Silagem de grãos úmidos. In: SIMPÓSIO SOBRE NUTRIÇÃO DE BOVINOS, 7., 1999, Piracicaba. Anais... Piracicaba: Fundação de Estudos Agrários Luiz de Queiroz, 1999. p.69-88.

EMPRESA BRASILEIRA DE PESQUISA AGROPECUÁRIA EMBRAPA. Tabela de composição química e valores energéticos para suínos e aves. 3.ed. Concórdia: CNPSA, 1991. 97p. (Documentos, 19).

HOLMES, J.H.G.; BAYLEY, H.S.; HORNEY, F.D. Digestion of dry and high moisture maize in the stomach of the pig. British Journal of Nutrition, v.32, n.3, p.639-346, 1974.

JOBIM, C.C.; REIS, R.A.; RODRIGUES, L.R.A. Avaliação da silagem de grãos úmidos de milho (Zea Mays L.). Pesquisa Agropecuária Brasileira, v.2, n.3, p.311-331, 1997

LOPES, A.B.R.C.; BERTO, D.A.; COSTA, C. et al. Silagem de grãos úmidos de milho para suínos na fase inicial dos 8 aos $30 \mathrm{~kg}$. Boletim da Indústria Animal, v.58, n.2, p.81-190, $2001 \mathrm{a}$.

LOPES, A.B.R.C.; BERTO, D.A.; COSTA, C. et al. Silagem de grãos úmidos de milho para suínos nas fases de crescimento e terminação. Boletim da Indústria Animal, v.58, n.2, p.191-200, 2001 b.

LOPES, A.B.R.C.; LEONEL, M.; CEREDA, M.P. et al. Efeito do processo de ensilagem de grãos úmidos de milho nas características do amido. Brazilian Journal of Food Technology, v.5, n.96, p.177-181, 2002. (Nota prévia).

MATTERSON, L.D.; POTTER, L.M.; STUTZ, M.W. et al. The Metabolizable energy of feed ingredients for chickens. Agricultural Experiment Statistics, v.7, p.3-11, 1965.

NATIONAL RESEARCH COUNCIL - NRC. Nutrient requeriments of swine. 10.ed. Washington, D.C.: National University Press, 1998. $189 \mathrm{p}$.
OLIVEIRA, R.P.; FURLAN, A.C.; MOREIRA, I. Valor nutritivo e desempenho de leitões alimentados com rações contendo silagem de grãos úmidos de milho Revista Brasileira de Zootecnia, v.33, n.1, p, 146-156, 2004 .

PEKAS, J.C. Versatile swine laboratory apparatus for physiologic and metabolic studies. Journal of Animal Science, v.27, n.5, p.1301-1306, 1968.

PUPA, J.M.R.; KUANA, S.; ALBINO, L.F.T. et al. Valores de energia digestível e metabolizável do ácido fumárico, e a digestibilidade dos nutrientes da ração. In: CONGRESSO BRASILEIRO DE VETERINÁRIOS ESPECIALISTAS EM SUÍNOS, 9., 1999, Belo Horizonte. Anais... Belo Horizonte, ABRAVES, 1999. p.437-438.

RANGRAB, L.H.; SEDOSVKI, J.; LIMA, G.J.M.M. Avaliação do desempenho produtivo de leitões submetidos à silagem de grão úmido de milho na fase de creche. In: REUNIÃO ANUAL DA SOCIEDADE BRASILEIRA DE ZOOTECNIA, 41., 2004 Campo Grande. Anais... Campo Grande: Sociedade Brasileira de Zootecnia/Gmosis, [2004]. (CD-ROM).

SHAVER, R.D. Colheita e armazenamento de milho para a produção de silagem de alta qualidade para vacas leiteiras. In: NOVOS ENFOQUES NA PRODUÇÃO E REPRODUÇÃO DE BOVINOS, 4., 2000, Passos. Anais... Passos: CONAPEC Jr. \& CBRA, 2000. p.63-66.

STATISTICAL ANALYSIS SYSTEM - SAS. User's guide: Statistics. Version 6., 12.ed. Cary: 1998. 1290p.

TÓFOLI, C.A.; BERTO, D.A.; TSE, M.L.P. et al. Avaliação nutricional da silagem de grãos úmidos de milho com diferentes teores de óleo para leitões na fase de creche. Arquivo Brasileiro de Medicina Veterinária e Zootecnia, v. 58 , n.6, p.1206-1213, 2006.

TOSSENBERGER, J.; LIEBERT, F.; SCHULZ, E. Zum einfluss von phytase auf de bau von phytaten verschiedener herkunfte. In: VITAMINE UND WEITERE ZUSATZSTOFFE BEI MENSC TIER SYMPOSIUM, 4., 1993. Jena/Thüringen. Proceedings... Jena: Wissenschaftlicher Fachverlag, 1993. p.365-370.

TRINDADE NETO, M.A.; LIMA, J.A.F.; BERTECHINI, A.G. et al. Dietas e níveis protéicos para leitões desmamados aos 28 dias de idade - fase inicial. Revista da Sociedade Brasileira de Zootecnia, v.23, n.1, p.92-99, 1994.

TSE, M.L.P.; BERTO, D.A.; TOFOLI, C.A. et al. Valor nutricional da silagem de grãos úmidos de milho com diferentes graus de moagem para leitões na fase de creche. Arquivo Brasileiro de Medicina Veterinária e Zootecnia, v.58, n.6, p.1214-1221, 2006.

ZANOTTO, D.; MOTICELli, C.; MAZZUCO, C. Implicações da granulometria de ingredientes de rações sobre a produção de suínos e aves. In: SIMPÓSIO LATINO-AMERICANO DE NUTRIÇÃO DE SUÍNOS E AVES, 1995, Campinas. Anais... Campinas: Colégio Brasileiro de Nutrição Animal, 1995. p.166.

ZANOTTO, L.D.; BELLAVER, C. Método de determinação da granulometria de ingredientes para o uso em rações de suínos e aves. (S.1.): Centro Nacional de Pesquisa de Suínos e Aves/EMBRAPA, 1996. p.1-5 (Comunicado técnico, 215).

ZARDO, A.O.; LIMA, G.J.M.M. Alimentos para suínos. Boletim Informativo BIPERS, v.8, n.12, p.7-71, 1999. 